Working Paper 9307

\title{
LOAN SALES, IMPLICIT CONTRACTS, AND BANK STRUCTURE
}

by Joseph G. Haubrich and James B. Thomson

Joseph G. Haubrich is an economic advisor and James B. Thomson is an assistant vice president and economist at the Federal Reserve Bank of Cleveland. The authors would like to thank Christopher Pike for excellent research assistance, Allen Berger for advice and for sharing his capital programs, and Rebecca Demsetz for helpful comments.

Working papers of the Federal Reserve Bank of Cleveland are preliminary materials circulated to stimulate discussion and critical comment. The views stated herein are those of the authors and not necessarily those of the Federal Reserve Bank of Cleveland or of the Board of Governors of the Federal Reserve System.

October 1993 


\begin{abstract}
We document some recent changes in the market for loan sales.

We use a Tobit model to characterize the determinants of loan sales and purchases by banks, relating quantities bought and sold to bank size, capital, risk, and funding mode. The results, though not definitive, broadly confirm the Pennacchi model of sales. Other data cast doubt on the importance of mergers and acquisitions for this market and on the comparability of different data sources.
\end{abstract}




\section{INTRODUCTION}

A revolution now challenges the very essence of traditional banking: making and booking loans. Increasingly, banks both large and small sell their commercial and industrial loans. These sales take place without a guarantee from the government or the bank, and without being bundled into securities. The ramifications of a closely held asset becoming a marketable security oblige bank managers, regulators, and policymakers to rethink the role banks play in the economy and the role government plays in the banking sector.

The emerging loan sales market can illuminate a number of issues. It offers a chance to observe a new market developing in a regulated industry whose reporting requirements guarantee a wealth of data not usually available. It provides a laboratory for studying the origination and information functions of bank lending, separate from the investment function. From a public policy perspective, an understanding of the loan sales market is important in assessing the importance and competitiveness of domestic banks. For example, recent reports on foreign bank lending in the United States missed the distinction between loans held and loans originated and thereby overstated the involvement of foreign banks.

To fully comprehend the implications of loan sales for financial intermediation, we need to understand what caused the surge in loan sales. To what extent have regulations and market pressures -- binding capital requirements, the need to diversify, or a shift in regional economies -created the demand and supply? Moreover, have fundamental changes in institutions and information technology allowed the loan sale to become a feasible contract, and thus a suitable solution for these problems?

The answers to these questions will determine whether loan sales are here to stay, or whether they represent an epiphenomenon on the financial scene, their market vulnerable to a shift in regulation or leverage policy. Even accepting the hypothesis of a shift in information technology leaves many open questions. On the one hand, a technology that makes bank loans marketable may lead to disintermediation. The number of loans with which banks have a special advantage declines as the supply of nonmarketable assets dwindles. On the other hand, the technology may allow banks to make and book loans that even they previously found too 
http://www.clevelandfed.org/Research/Workpaper/Index.cfm

information-intensive. Thus, banks retain their traditional role as intermediaries, but with slightly different assets.

While the ultimate goal of this research is to understand the factors that drive the loan sales market, the present paper has a much more modest goal. We aim to characterize the determinants of loan sales and purchases by banks, and thus to understand the importance of size, capital, and funding mode in the decision to buy and sell loans. We hope this work serves as a foundation for more advanced studies that more directly confront the basic issues of why the loan sale is a credible contract and how shifts in information technology, regulatory practice, and market forces influence the market. Still, by digging into the details we can begin to answer these questions. We can find out how bank size and capital affect loan sales, and how important "informationally special" transactions -- such as sales of well-collateralized merger and acquisition loans, or sales to subsidiaries -- are in the market.

The general strategy of our work is to use the individual bank data from the Federal Financial Institutions Examination Council's Quarterly Reports of Income and Condition (call reports) to estimate the determinants of loan sales and purchases. We supplement these results by examining other data sources, such as the Federal Reserve's Senior Loan Officer Opinion Survey and Weekly Reporting Banks series. The sample period includes the recent recession and the downturn in the loan sales market and thus provides an opportunity to take a deeper look at these issues. One distinguishing feature of our work on the econometric side is the use of Tobit analysis. This has the advantage of explicitly taking into account the many banks that do not sell (or buy) loans, without ignoring the information about the volume of those who do participate. Its disadvantage is that correcting for heteroskedasticity and autocorrelation is more difficult.

The remainder of the paper is as follows: Section II describes the basic institutional details of the loan sales market. The difference between selling loans and selling stocks and bonds lies behind the theoretical and empirical issues addressed in sections III and IV. ${ }^{1}$ Section III presents a quick overview of a theory we use to organize our thoughts on the market, and section IV, the

\footnotetext{
'More detailed information appears in Haubrich (1989), Gorton and Haubrich (1990), and Gorton (1991).
} 
http://www.clevelandfed.org/Research/Workpaper/Index.cfm

heart of the paper, presents the empirical results. Conclusions and suggestions for future work appear in section $\mathrm{V}$.

\section{THE LOAN SALES MARKET}

A bank sells a loan by promising its payment stream to the buyer. In the most common type of loan sale, the participation, the original contract between the bank and the borrower remains in place, and the bank continues to collect payments, oversee the collateral, and examine the books. In many cases (termed silent participations), the borrower does not even know that the loan has been sold. A less common but still important type of loan sale, the assignment, transfers the debtor-creditor relationship to the buyer, giving the buyer some rights to take direct action against the borrower. Assignments do not completely remove the original bank from the picture, however, because that bank may retain obligations, such as loan commitments, to the borrower. The rarest and most complete type of loan sale is the novation. Like the sale of a stock or bond, a novation completely transfers all rights and obligations of the selling bank to the buyer; the originator leaves the picture entirely.

Two legal and accounting issues shape the loan sales market. Banks want to remove the loan from their balance sheet and also desire to avoid federal securities laws. To remove the loan from the balance sheet, and treat the transaction as an asset sale rather than a borrowing, the bank must show that the risk of the loan has been shifted to the buyer. This means that the entire loan must be sold off, that the seller bank can provide no recourse to the buyer, and that the loan must be sold to maturity. (For more detail, see Morris [1991] or Gorton and Haubrich [1990].)

Banks also hope to avoid having loan sales classified as securities, thereby sidestepping federal securities regulation and the associated disclosure laws, reporting requirements, and increased legal penalties. In addition, they hope to stay clear of any brush with the Glass-Steagall prohibitions against underwriting securities. The courts have generally held that loan sales are not securities, in part because banks have taken pains to structure the contracts properly. For example, loans are rarely resold because such a resale would make the loan look too much like a security. 
Banks sell several types of loans. Asset Sales Report, a newsletter, tracks loan sales for nine major banks. As of January 25,1993 , the total balance outstanding for this group was $\$ 58$ billion, of which $\$ 5$ billion was in loans with maturities under a year, and $\$ 53$ billion was in loans with maturities of one year or more. Maturity has increased as the market has developed. In the early 1980s, banks mainly sold short-term (under 90 days) domestic commercial and industrial (C\&I) loans made to investment-grade (BBB or better) borrowers. Since then, maturity has lengthened and loans to lower-quality borrowers have predominated. Among large banks, the share of outstanding loans sold that were obligations to investment-grade borrowers dropped to 37 percent by 1989.

Loans are bought and sold by many types of banks, though large banks, both foreign and domestic, predominate. Nonbank (and even nonfinancial) firms also buy loans, which results in some loans leaving the banking system entirely. Loan purchases by foreign banks and nonbank firms limit the scope of our empirical results, which depend on the bank call reports, and so are restricted to domestic banks and insured domestic offices of foreign banks. Table 1 lists the top 25 domestic sellers and buyers of loans. Though large banks figure prominently in both panels, they dominate less on the purchase side.

The final notable aspect of this market is its pricing structure. Prices of highly rated loans closely track commercial paper and LIBOR. Not surprisingly, yields on lower-rated loans show a greater spread. Asset Sales Report (February 1, 1993) lists the spread between the 30-day A1/P1 loan sales yield and commercial paper as -2 basis points, showing that short-term loans can even sell at a premium to commercial paper. For loans with the lower rating of $A 2 / \mathrm{P} 2$, the spread was 18 basis points.

\section{THEORETICAL BACKGROUND}

As a basic framework to think about the issues surrounding loan sales, we use a simplified version of the model developed by Pennacchi (1988). ${ }^{2}$ This model is a state-preference version of the Miller (1977) debt model as extended to banks by Orgler and Taggart (1983). Corporate

\footnotetext{
2 For a somewhat different approach, see Mester (1992) or Carlstrom and Samolyk (1993).
} 
income taxation gives a tax advantage to debt, but debt increases agency and bankruptcy costs, providing a determinate debt-to-equity ratio.

In this version of the model, the bank adds value by providing monitoring services. If it monitors a loan at level $\mathrm{a}=\bar{\alpha}$, the loan will not default and will provide a certain return of $\left(1+r_{n}\right)$. If the bank monitors at a level below $\bar{a}$, then the loan defaults with certainty.

Apart from selling loans, banks have two sources of funds: deposits and equity. Deposits have a tax advantage in that their interest is deductible as a business expense, but they have an additional cost of reserve requirements. Banks have a constraint on these funding sources, namely, a capital requirement that the debt (that is, deposit) to equity ratio not exceed a limit $\zeta$. If we denote the return on deposits as $r_{d}$ and the return on equity as $r_{e}$, the marginal cost of raising funds internally, $\mathrm{T}$, is given by

(1) $\quad r_{l}=\frac{r_{e} /(1-t)+\zeta r_{d}}{1+\zeta(1-\rho)}$

where $t$ is the corporate tax rate and $\rho$ is the reserve requirement. Without loan sales, the bank makes loans until the return on the loan, net of monitoring costs, equals the cost of funds needed to fund the loan, or $\mathrm{T}^{=} \mathrm{r}_{\mathrm{n}}-\mathrm{c} \bar{a}$.

Loan sales introduce a new funding possibility. The bank can now make a loan and sell a fraction $b$ of it. This sold fraction is removed from the bank's balance sheet and is, in effect, funded by the loan buyer. Pennacchi calculates the cost of funding a sold loan as

$$
\text { (2) } \quad r_{1}-\bar{b}\left(1+r_{n}\right) \frac{r_{1}-r_{d}}{1+r_{d}}
$$

where $\bar{b}$ denotes the fraction of the loan sold. It is assumed that this fraction is small enough so that the bank retains an incentive to monitor the loan.

Figures 1 and 2 illustrate how this model explains loan sales and loan purchases. In each case, banks have some degree of local market power in both loans and deposits, reflected in a downward-sloping demand curve for loans and an upward-sloping deposit supply curve. Banks 
sell loans when they have a large supply of profitable loans relative to their funding. Banks buy loans when they have a large supply of funding relative to their loan opportunities.

Figure 1 is for a bank that sells loans. The supply of loans, locus NAN', slopes downward until point $\mathrm{A}$. At this point, local loans become less profitable than money-market investments paying a return $r_{m}$. Likewise, raising core deposits is cheaper than the cost of purchasing funds in the competitive national deposit market. Consequently, the deposit supply curve DSD' rises until $r_{d}=r_{m}$, after which the cost of internal funds remains a constant $r_{I}$, where $r_{I}$ is given by equation (1) with $r_{d}$ set to $r_{m}$.

Loans are sold in the national market and the bank is a price-taker in the loan sales market. This means that all loans sold are priced to yield the market rate of return, $r_{m}$, to the buyer. The implicit price of funding the fraction $\bar{b}$ of each loan sold is therefore $\mathrm{r}_{\mathrm{m}}$. Hence, when the price of internal funds is below $r_{m}$, the bank holds the loans it originates. When the price of internal funds rises above $r_{m}$, however, selling loans is profitable because it enables the bank to lower the

cost of funding the loan from $\mathrm{r}_{\mathrm{I}}$ to $\bar{b} \mathrm{r}_{\mathrm{m}}+(1-\bar{b}) \mathrm{r}$. The bank makes loans until supply and demand meet (at $N^{*}$ ) but it fully books loans only up to point $S$; the difference is loan sales.

Figure 2 shows a bank that buys loans. The curve NAA' describes lending opportunities, and the curve DSD' describes funding opportunities. The bank can fund assets up to point $S$, but it has fewer profitable loan originations and instead resorts to the money market. Admittedly, it will also invest in T-bills, commercial paper, and bankers' acceptances, but some of the investment may go to loan purchases.

In explaining the empirical results of the next section, we will often refer to these diagrams to conduct simple comparative static exercises such as changing market interest rates, capital levels, or loan demand.

\section{EMPIRICAL RESULTS}

Our work in this section has one basic goal. We hope to characterize the determinants of loan sales and purchases -- to find out what determines who buys, who sells, and how much. We pursue this both by estimating an econometric specification of loan sales and purchases using the 
detailed balance-sheet and income statement information for insured commercial banks, and by a less formal examination of some specialized data sources.

While we cannot formally test the relative importance of capital requirements and shifts in information technology in the emergence and growth of the loan sales market, our results can address the impact of many factors such as bank size, merger and acquisition loans, and sales to subsidiaries.

Our main data source in this endeavor consists of the FFIEC's Quarterly Reports of Income and Condition, or call reports. Our sample starts in March 1984, just after a major revision of the reports (which means ignoring one quarter, December 1983, of loan sales data), and ends in December 1992, the latest available quarter. Loan purchases start later, in the first quarter of 1988 .

Figure 3 plots the aggregate level of loan sales and purchases. Figure 4 plots sales and purchases as a percentage of net loans. Note the explosion in the loan sales market between 1986 and 1988, and the subsequent collapse from 1989 to 1991 . Loan purchases, though much smaller than sales, remained fairly steady over the entire period. The relatively small volume of purchases serves as a reminder that not only domestic banks purchase loans.

\section{A. Call Report Data}

The empirical work using the call reports runs the dependent variable, loan sales or loan purchases, against a set of independent variables that proxy for individual bank characteristics and market conditions. We first use the entire available sample for loan sales and purchases. Next, we use a more restricted time period for which we have data on off-balance-sheet items and on highly leveraged transactions. This gives us more explanatory variables but a shorter time period.

To provide a benchmark case, we first run ordinary least squares. While the parameter estimates are all very significant, the $\mathrm{R}^{2}$ is extremely low. The low $\mathrm{R}^{2}$ is not all that surprising because many banks do not sell loans; of the 477,000 observations, 294,000 had no loan sales.

To correct econometrically for the large number of zero observations for the dependent variable requires the use of a limited dependent variable method. We use Tobit, instead of logit or 
http://www.clevelandfed.org/Research/Workpaper/Index.cfm

probit, because we do not wish to ignore the information about the quantity of loans sold (or bought). ${ }^{3}$ Figure 5 shows the importance of this distinction. The variation in sales comes not from changes in the number of banks selling loans but rather in the volume of loans sold by banks in the market.

\section{Loan Sales}

In the loan sales equations, the dependent variable, LSRAT (the ratio of loans sold to total assets), is regressed against 19 independent variables. Definitions of the variables used in the study can be found in table 2 . Five of these are dummy variables for size to control for different size classes of banks. Another five dummy variables indicate the banks' regional location (Southeast, Midwest, High Plains, Southwest and West). Seven variables (Caprat, Hotrat, Holdco, Ttass, Chrrat, Nlrat, Netimarg) are introduced to proxy for individual bank characteristics. These variables capture banks' size, capital position, use of the national money market, and position on lending. They act as a natural starting place for an examination of the determinants of loan sales. Two other variables, Tsprd and Baasprd, are included to proxy for general market conditions. Table 3 presents the results.

What do the Tobit estimates tell us? Bank size, measured by total assets, has a positive effect on loans sold. The coefficients on the size dummies and on the log of total assets are negative and significant. The size dummies indicate a positive relationship between size and loan sales. However, the negative coefficient on Ttass suggests that the relationship between loan sales and size is highly nonlinear. That is, while large banks sell a higher percentage of their loans than do small banks, within a particular size class the larger you become, the fewer loans you sell.

A bank's geographic location also appears to influence loan sales. Other things being equal, banks located in the Northeast region (the Boston, New York, and Philadelphia Federal Reserve Districts) were the least likely to sell loans, and banks in the High Plains states were the most likely to do so. However, it is not clear what is driving the regional variation in loan sales. The weakness in the loan sales market in the Northeast should not be attributed to a high bank failure rate because the dummy for the Southwest, another high-failure area, came in large and

\footnotetext{
${ }^{3}$ For other interesting approaches, see Pavel and Phillis (1987) and Berger and Udell (1992).
} 
http://www.clevelandfed.org/Research/Workpaper/Index.cfm

positive. Moreover, differences in loan sales also appear across regions with strong banking sectors. The coefficient on the Midwest dummy is seven times larger than on the Southeast dummy.

The higher a bank's capital ratio, the less likely it is to sell loans. This accords with the story told in section III. Banks that find the capital constraint binding will find it is cheaper to originate and then sell a loan than to keep it on their books. ${ }^{4}$ For loan sales, the positive coefficient on Hotrat is consistent with the theoretical model's prediction that banks with good lending opportunities will sell loans. That is, a bank with a large number of profitable lending opportunities will fund only a fraction of loans originated in the national money market (beyond the kink in the DD' curve of figure 1), funding the remainder off its balance sheet through sales.

Holding-company affiliation is positive and significantly related to loan sales. This is consistent with evidence from the weekly reporting banks, given below, that a nontrivial amount of loan sales is made between affiliates of the same holding company. Moreover, it is consistent with the theory in section III, to the extent that interaffiliate loan sales are used to minimize the cost of funding new loans.

Chrrat, net charge-offs as a percent of assets, has a coefficient that is positive but insignificant, both statistically and economically. Therefore, we do not find evidence of a lemons market problem associated with loan sales.

Net loans and leases enter positively, reflecting that a bank with good lending opportunities makes a lot of loans, some of which it sells and some of which it keeps on its balance sheet. The positive and significant coefficient on the net interest margin supports this interpretation, as high margins indicate a bank with a good supply of profitable loans.

The two spread variables measuring market conditions also have an impact on loan sales. The coefficient on Tsprd is negative but not significant at the 5 percent confidence level. A negative coefficient on the term structure spread suggests that with a steep term structure, banks find it profitable to fund new, presumably longer-term, loans on their books with funds purchased

\footnotetext{
4 This result is sensitive to the limited dependent variable problem as the sign of Caprat changes when we move from OLS to Tobit in order to estimate the model.
} 
http://www.clevelandfed.org/Research/Workpaper/Index.cfm

in the national money market. The coefficient on Baasprd is positive and significant. A wide risk spread means that risky assets, such as loans, pay a high premium over safer assets, and are thus more desirable.

A natural question at this point is how well the above specification explains the data, or how good the fit is. Tobit regressions do not have a natural goodness-of-fit measure, but it is possible to get some idea of how well the Tobit does. We obtained the predicted values from the Tobit equation (following Maddala [1983, section 6.6]) for each bank in each quarter. We summed these across banks for each quarter, yielding an aggregate prediction of loan sales volume. Figure 6 plots the results along with the actual volume of loan sales. Clearly, this specification does not explain enough about loan sales to account for the rise and fall of market volume.

\section{Loan Purchases}

The equations for loan purchases are estimated over a shorter sample period because data on purchases do not become available until the first quarter of 1988. Table 4 reports the results for purchases. Overall, bank size is inversely related to loan purchases. That is, small banks tend to buy more loans than do large ones. However, mid-sized banks (between $\$ 500$ million and $\$ 5$ billion in assets) buy a greater fraction of loans than do either the smallest two size classes or the largest class. As with loan sales, the relationship size has a nonlinear impact on loan purchases. The positive coefficient on Ttass indicates that within size classes there is a positive relationship between size and loan purchases. Regional effects also remain important, and once again the High Plains dummy has the largest coefficient, and the implicit Northeast dummy the smallest.

Capital is positive and significantly related to loans bought. Furthermore, the coefficient on Hotrat, the proxy for purchased funds, is negative and significant. In other words, wellcapitalized banks that can fund new loans with inexpensive local deposits buy loans. This is consistent with the Pennacchi model in section III.

Holding-company affiliation is a factor influencing loan purchases. Other things being equal, banks in bank holding companies are more likely to purchase loans than are nonaffiliated 
http://www.clevelandfed.org/Research/Workpaper/Index.cfm

banks. As with loan sales, the behavior of Holdco suggests that bank holding companies use the loan sales and purchases between affiliates to manage their consolidated balance sheets.

The negative coefficient on the charge-off ratio argues for a form of comparative advantage. A bank adept at managing loans and assessing their value would have low charge-offs and would also have a comparative advantage in buying loans. The positive and significant coefficient on Nlrat, the percent of assets invested in loans, is consistent with the "comparative advantage" explanation.

Loan sales are positively related to loan purchases. This is consistent with a "threshold effect," whereby set-up costs and experience in one side of the market bring returns to the other side as well. The net interest margin has a negative impact, as expected, because banks with good lending opportunities do not purchase loans. Finally, unlike loan sales, neither of the market condition variables significantly affects loan purchases. The poor performance of Tsprd and Baasprd in the loan purchase equation is consistent with loan purchases being determined by local market variables, particularly by relative local lending and funding opportunities.

\section{HLT Subsample Results}

Tables 5 and 6 report the estimation results using the data on off-balance-sheet activity and highly leveraged transactions (HLTs), for which data exist only from the third quarter of 1990 to the fourth quarter of 1992 . The differences from the results given in previous tables may partly be due to a shorter sample period.

In the loan sales equation, two parameters change sign. The capital ratio switches from negative to positive. This may reflect a reputation effect: Buyers prefer loans from stronger, better-capitalized banks. The coefficient on the risk-spread proxy, Baasprd, changes from positive to negative. What may lie behind the change is that over the period for which we have data for HLT loans, the loan sales market was in a steep decline, reversing the general growth trend over the total period.

The HLT and off-balance-sheet variables are both positively related to loan sales. This indicates that some banks are taking a "merchant banking" stance, engaging in a variety of hightech finance. There may be an even more direct relationship. Because HLT loans may be the type 
http://www.clevelandfed.org/Research/Workpaper/Index.cfm

that are sold, a large presence in the HLT market indicates a propensity to sell loans. Though this may be important, the small coefficients and insignificant Chi-squared values show that this is by no means the only explanation of loan sales.

In the loan purchases equation, there are a number a notable differences between the HLT subsample results and those of the full sample. First, all size dummies become negative, indicating that the largest banks buy the largest proportion of loans. While not significant at the 95 percent confidence level, the positive coefficient on the log of total assets confirms the size effect.

Second, the coefficients on Caprat and Hotrat reverse signs and the positive coefficient on the term structure spread is significant. The behavior of these three proxy variables is consistent with large banks becoming more active buyers of loans. Larger banks historically hold smaller capital cushions, rely more heavily on national money markets for funding, and have lending opportunities that are more closely related to market conditions than are those of smaller banks.

As with loan sales, off-balance-sheet activities and HLT loans are both positively related to loan purchases; this relationship is consistent with the "merchant banking" explanation. Moreover, the positive sign on Hltrat confirms the Pennacchi model of section III. A firm with slack local loan demand goes to the national market -- and buys loans and makes HLT loans.

\section{Data Snooping}

Our Tobit regressions have yielded a number of insights about factors determining bank participation in the loan sales market and are largely consistent with the Pennacchi model. Unfortunately, however, our empirical specification does a dismal job of capturing the runup and subsequent collapse of the market. (See figure 3.) Because one of the purposes of this research is to characterize the determinants of loan sales and purchases in order to provide a foundation for future research, we attempt to control for two factors that may have influenced the market: the 1990-91 recession and the impact of Security Pacific and Bankers Trust. However, this exercise falls within the category of data snooping; therefore, caution must be used in interpreting the results. ${ }^{5}$

\footnotetext{
${ }^{5}$ For a description of data snooping and the attendant biases in test results, see Lo and MacKinlay (1990).
} 
Recessions could be expected to affect the loan sales market by reducing the demand for bank loans and, in turn, reducing the supply of loans booked for sale. In figure 1 the effect of the recession would be a downward shift in the lending opportunities curve and a rightward shift in point S. Given that the recent recession coincided with the peak and subsequent downturn of the loan sales market, and given the slow growth of bank credit in the ongoing recovery, controlling for the recession could improve the model's fit.

Anecdotal evidence suggests that some of the runup and subsequent collapse of the loansales market may be due to the behavior of two banks. The first, Bankers Trust, was a major player in this market, especially in the sale of mergers and acquisitions loans; this institution effectively exited the market around the time that it peaked. Security Pacific Bank was a driving force in the development and growth of this market. Security Pacific's asset quality problems, which resulted in its acquisition by Bank of America in April 1992, eliminated it as major player in the loan sales market after the market peaked in 1990.

To investigate the sensitivity of our results to these two factors, we reestimate the full sample loan sales equation with a dummy variable for the recession, RECESS, omitting Bankers Trust and Security Pacific from the sample. The results, shown in table 7, are very similar to those in table 3. The coefficient on RECESS is negative and significant. Thus, as expected, the 1990-91 recession had a negative impact on loan sales. The only notable difference in the results when RECESS is included as a regressor is that the coefficient on Tsprd becomes negative and significant. Moreover, the results' lack of sensitivity to the omission of Bankers Trust and Security Pacific suggests that outliers are not driving the results. Unfortunately, this datasnooping specification of the loan sales equation failed to improve the fit of the model.

\section{B. Supplemental Data}

The Tobit specification using call report data leaves many puzzles unexplained. Some popular and interesting explanations cannot be addressed by call report data and can be evaluated only with other data sets which provide their own perspective (and puzzles) on the matter. 
http://www.clevelandfed.org/Research/Workpaper/Index.cfm

One popular explanation links the loan sales market with the mergers and acquisitions (M\&A) market. Banks with large chunks of M\&A financing had the desire to reduce their exposure to any one borrower. Moreover, because these loans were collateralized senior debt and were obligations of large, well-known corporations, the banks also had the ability to sell the loans. As the M\&A market dried up, loan sales activity also fell. Some evidence supports this view, as the Senior Loan Officer Opinion Survey on Bank Lending Practices (LPS) often showed that M\&A activity accounted for a large share of the loan sales of the reporting banks. For example, respondents to the August 1989 survey reported that $44.5 \%$ of loan sales represented financing for mergers and acquisitions.

For the market as a whole, however, merger activity cannot explain the pattern of loan sales volume. Figure 7 plots loan sales and total M\&A activity (from Mergers and Acquisitions magazine). This series overstates bank activity in the mergers market because banks were not the only source of funding. Even so, the level of M\&As is simply too low to account for either the rise or the fall of loan sales volume. A closer look at figure 7 suggests that merger activity could have played a major role before 1987, when the market first developed, but not since.

A comparison of figure 7 with the LPS survey shows that the experience of the survey banks does not always extend to the entire market. In this case, the concentration of M\&A loans among survey banks is an aberration.

The mergers explanation appeals partly because it solves the contracting problem at the heart of the market by positing that sold loans are really very close to marketable securities. A related possibility is that it is not the nature of the loan itself that solves this problem, but rather the relationship between the buyer and the seller. Specifically, a sale to a subsidiary avoids many informational problems. The weekly reporting banks provide data on this point. Figure 8 plots loan sales of weekly reporting banks from 1984 to the present, along with loans sold to nonbank subsidiaries. One more note of caution: The pattern of sales for this sample of banks does not match that of the total market, so that the large weekly reporting banks are not representative of the entire market. Nonetheless, for this subset, sales to nonbank subsidiaries make up a large, and reasonably steady, fraction of all loans sold. 
The weekly reporting banks present their own puzzles. Why did the bottom drop out of the market in 1990? Is there any connection to the LPS survey, in which respondents reported that loan sales dropped from 56 in 1990 to 17 in 1991, only to rebound to 57 in 1992 ?

\section{CONCLUSION}

Loan sales are a phenomenon in modern finance that signals a change in the role of banks as intermediaries. To fully comprehend the ramifications of the marketability of bank loans for banks, for bank regulation, and for the role of federal deposit insurance, one must understand the forces that drive the loan sales market. As a first cut at addressing the relative influences of technological change, legal and institutional factors, and bank regulation on the development and growth of this market, we look at the determinants of loan sales and purchases by banks.

We find that bank size, capitalization, funding strategy, and investment strategy are all significant determinants of loan sales and loan purchases. Other bank-specific factors such as location, holding-company affiliation, and participation in the mergers and acquisitions market, as well as general credit-market condition variables, influence loan sales and purchases. Overall, the empirical results support the theoretical (Pennacchi) model of loan sales and purchases presented in section III.

Unfortunately, however, many issues remain unresolved. Our empirical model is not able to explain the sharp rise of the market at the end of the 1980 s and its equally sharp decline in the early 1990s. In addition, call report data do not give us a good handle on the extent to which this market is used by bank holding companies to minimize funding costs for bank loans. Interaffiliate sales and purchases of loans may paint a very different picture of this market and its implications for bank-intermediated credit. Finally, while our results indicate that capital is an important determinant of loan sales, we cannot separate the relative influences of capital regulation and market forces, as well as technology, on the development and growth of the loan sales market. 


\section{REFERENCES}

Berger, Allen N., and Gregory F. Udell, "Securitization, Risk, and the Liquidity Problem in Banking," in Structural Change in Banking, Michael Klausner and Lawrence J. White, eds., Irwin, Homewood, $\mathrm{L}, 1992$, pp. 227-91.

Carlstrom, Charles T., and Katherine A. Samolyk, "Loan Sales as a Response to Market-Based Capital Constraints," Federal Reserve Bank of Cleveland, Working Paper, forthcoming 1993.

Gorton, Gary B., "The Growth and Evolution of the Loan Sales Market," in The Commercial Loan Resale Market, Jess Lederman, Linda E. Feinne, and Mark Dzialga, eds. Probus, Chicago, 1991, pp. 15-53.

Gorton, Gary B., and Joseph G. Haubrich, "The Loan Sales Market," in Research in Financial Services: Private and Public Policy," George G. Kaufman, ed., vol. 2, 1990, JAI Press, Greenwich, CT, pp. 85-135.

Haubrich, Joseph G., "An Overview of the Market for Loan Sales," Commercial Lending Review, vol. 4, no. 2, Spring 1989, pp. 39-47.

Lo, Andrew W., and A. Craig MacKinlay, "Data-Snooping Biases in Tests of Financial Asset Pricing Models," The Review of Financial Studies, vol. 3, no. 3, 1990, pp. 431-67.

Maddala, G.S., Limited-dependent and Qualitative Variables in Econometrics, Econometric Society Monographs No. 3, Cambridge University Press, New York, 1983.

Mergers and Acquisitions magazine, various issues, 1988-1992.

Mester, Loretta, "Traditional and Nontraditional Banking: An Information Theoretic Approach," Journal of Banking and Finance, vol. 16, 1992, pp. 545-66.

Miller, Merton, "Debt and Taxes," Journal of Finance, vol. 32, June 1977, pp. 261-75.

Morris, David M., "Accounting for Commercial Loan Sales," in The Commercial Loan Resale Market, Jess Lederman, Linda E. Feinne, and Mark Dzialga, eds., Probus, Chicago, 1991, pp. 99-130.

Orgler, Yair E. and Robert A. Taggart, Jr., "Implications of Corporate Capital Structure Theory for Banking Institutions," Journal of Money, Credit and Banking, vol. 15, May 1983, pp. 212-21.

Pavel, Christine, and Avid Phillis, "To Sell or Not to Sell: Loan Sales by Commercial Banks," Federal Reserve Bank of Chicago, Mimeo, 1987.

Pennacchi, George G., "Loan Sales and the Cost of Bank Capital," Journal of Finance, vol. 43, no. 2, June 1988, pp. 375-96. 
Top 25 Domestic Sellers and Buyers of Loans

$\begin{array}{cl}\text { Rank } & \text { Bank Name } \\ & \\ 1 & \text { Citibank NA } \\ 2 & \text { Bank of America NT\&SA } \\ 3 & \text { Chemical Bk } \\ 4 & \text { Mellon Bk NA } \\ 5 & \text { Morgan Guaranty TC of NY } \\ 6 & \text { Chase Manhattan Bk NA } \\ 7 & \text { First NB of Chicago } \\ 8 & \text { Crestar Bk } \\ 9 & \text { Signet Bk - VA } \\ 10 & \text { Bank of Tokyo TC } \\ 11 & \text { Wachovia Bk N Carolina } \\ 12 & \text { Texas Commerce Bk NA } \\ 13 & \text { Corestates Bk NA } \\ 14 & \text { Continental Bk NA } \\ 15 & \text { Bank of New York } \\ 16 & \text { Wachovia Bk GA NA } \\ 17 & \text { First Interstate Bk CA } \\ 18 & \text { Bankers TC } \\ 19 & \text { LaSalle NB } \\ 20 & \text { Security Pacific Nat. TC } \\ 21 & \text { First Union NB NC } \\ 22 & \text { First NB of Boston } \\ 23 & \text { Trust Co Bk } \\ 24 & \text { Pacific Inland Bk } \\ 25 & \text { Pittsburgh NB } \\ & \end{array}$

Loan

Sales

$\$ 17,365,000$

$15,741,000$

$15,139,000$

$7,599,923$

$4,011,011$

$3,643,626$

$2,134,235$

$2,067,692$

$1,795,299$

$1,215,942$

$1,050,157$

978,263

899,293

858,000

800,876

661,984

652,649

611,000

566,461

563,005

551,867

422,284

387,425

366,103

285,839
Loan

Purchases

$\$ \quad 69,000$

293,000

343,000

64,800

34,000

832

179,455

102

0

0

$1,333,353$

11,881

12,000

88,172

4,839

542,000

32,924

68,093

133,243

55,152

14,733

175,572 


$\begin{array}{cl}\text { Rank } & \text { Bank Name } \\ & \\ 1 & \text { Connecticut NB } \\ 2 & \text { Nationsbank NC NA } \\ 3 & \text { Bankers TC } \\ 4 & \text { JP Morgan Delaware } \\ 5 & \text { Shawmut Bk NA } \\ 6 & \text { Chemical Bk } \\ 7 & \text { Central Bk NA } \\ 8 & \text { Bank of America NT\&SA } \\ 9 & \text { Huntington NB } \\ 10 & \text { Rhode Island Hosp TR NB } \\ 11 & \text { Trust Co. of New Jersey } \\ 12 & \text { Nationsbank of FL NA } \\ 13 & \text { National Westminster Bk U } \\ 14 & \text { Crestar Bk } \\ 15 & \text { Pittsburgh NB } \\ 16 & \text { Bank of Hawaii } \\ 17 & \text { Texas Commerce Bk NA } \\ 18 & \text { First NB of Boston } \\ 19 & \text { Old Kent B\&TC } \\ 20 & \text { Maryland NB } \\ 21 & \text { Comerica Bk } \\ 22 & \text { First Union NB FL } \\ 23 & \text { National City Bk } \\ 24 & \text { Nationsbank TX NA } \\ 25 & \text { Southtrust Bk GA NA } \\ & \end{array}$

$\begin{array}{rr}\text { Loan } & \text { Loan } \\ \text { Purchases } & \\ & \\ \$ 673,880 & 29,430 \\ 636,169 & 81,166 \\ 542,000 & 611,000 \\ 534,956 & 0 \\ 465,767 & 0 \\ 343,000 & 15,139,000 \\ 318,886 & 1,657 \\ 293,000 & 15,741,000 \\ 281,090 & 203,967 \\ 255,107 & 0 \\ 231,720 & 1,955 \\ 230,972 & 171,502 \\ 220,346 & 1,377 \\ 179,455 & 2,067,692 \\ 175,572 & 285,839 \\ 168,910 & 29,370 \\ 133,353 & 978,263 \\ 133,243 & 422,284 \\ 114,943 & 87,781 \\ 114,914 & 172,761 \\ 114,791 & 139,835 \\ 110,034 & 0 \\ 109,746 & 42,037 \\ 105,178 & 4,018 \\ 101,006 & 9,417\end{array}$

Source: Call reports. 
LSRAT The ratio of loans sold to total assets.

LBRAT The ratio of loans purchased to total assets.

DUMSE Dummy variable for banks located in the Southeast region. Equals 1 if the bank is in the Richmond or Atlanta Federal Reserve District.

DUMMW Dummy variable for banks located in the Midwest region. Equals 1 if the bank is in the Cleveland, Chicago, or St. Louis Federal Reserve District.

DUMHP Dummy variable for banks located on the High Plains region. Equals 1 if the bank is in the Minneapolis or Kansas City Federal Reserve District.

DUMSW Dummy variable for banks located in the Southwest region. Equals 1 if the bank is in the Dallas Federal Reserve District.

DUMWE Dummy variable for banks located in the West region. Equals 1 if the bank is in the San Francisco Federal Reserve District.

DSZ1 Dummy variable for size. Equals 1 if total assets are less than $\$ 50$ million, and 0 otherwise.

DSZ2 Dummy variable for size. Equals 1 if total assets are between $\$ 50$ million and $\$ 100$ million, and 0 otherwise.

DSZ3 Dummy variable for size. Equals 1 if total assets are between $\$ 100$ million and $\$ 500$ million, and 0 otherwise.

DSZ4 Dummy variable for size. Equals 1 if total assets are between $\$ 500$ million and $\$ 1$ billion, and 0 otherwise.

DSZ5 Dummy variable for size. Equals 1 if total assets are between $\$ 1$ and $\$ 5$ billion, and 0 otherwise.

RECESS Dummy variables for the 1990-91 recession.

Caprat The ratio of bank capital to total assets.

Hotrat The ratio of "hot" funds to total assets, that is, deposits above $\$ 100,000$, brokered deposits, foreign deposits, and Fed funds purchased.

Holdco A dummy variable which equals 1 if the bank is part of a holding company, 0 if it is not. 
Ttass The log of total assets.

Chrrat The ratio of total charge-offs net of recoveries (a measure of losses on loans) to total assets.

Nlrat The ratio of net loans and leases to total assets.

Netimarg The net interest margin of the bank: total interest income less total interest costs, all divided by total assets.

Tsprd The spread between 30 year $\mathrm{T}$-bonds and 90 day $\mathrm{T}$-bills at the beginning of each quarter.

Baasprd The spread between Standard \& Poor's Baa bond portfolio and 90 day T-bills.

Offrat The ratio of off-balance-sheet activities, exclusive of loan sales, to total assets.

Hltrat The ratio of loans for highly leveraged transactions to total assets.

Source: Authors. 
Table 3

Loan Sales, Full Sample

A. Tobit Results

Noncensored Values $=182,762$

Left Censored Values $=294,079$

Observations with Missing Values $=4$

Log Likelihood for Normal -130948.811

\begin{tabular}{lcccc}
\multicolumn{1}{c}{ Variable } & Estimate & Std Err & Chi-square & PR $>$ CHI \\
Intercept & -0.2324704 & 0.016619 & 195.6756 & $2 . \mathrm{E}-44$ \\
DSZ1 & -0.1880172 & 0.007533 & 622.8842 & $0 . \mathrm{E}+00$ \\
DSZ2 & -0.1906599 & 0.006786 & 789.4551 & $0 . \mathrm{E}+00$ \\
DSZ3 & -0.1619715 & 0.006195 & 683.4916 & $0 . \mathrm{E}+00$ \\
DSZ4 & -0.1107057 & 0.006257 & 313.0594 & $5 . \mathrm{E}-70$ \\
DSZ5 & -0.0825235 & 0.005734 & 207.1438 & $6 . \mathrm{E}-47$ \\
DUMSE & 0.01162667 & 0.002345 & 24.58236 & $7 . \mathrm{E}-07$ \\
DUMHP & 0.1150077 & 0.002276 & 2553.964 & $0 . \mathrm{E}+00$ \\
DUMMW & 0.07971159 & 0.002183 & 1332.881 & $0 . \mathrm{E}+00$ \\
DUMSW & 0.10839645 & 0.002408 & 2026.585 & $0 . \mathrm{E}+00$ \\
DUMWE & 0.07895829 & 0.002676 & 870.8648 & $0 . \mathrm{E}+00$ \\
Caprat & -0.0307436 & 0.010721 & 8.222683 & .00414 \\
Hotrat & 0.10284555 & 0.003954 & 676.5113 & $0 . \mathrm{E}+00$ \\
Holdco & 0.05923403 & 0.001109 & 2854.545 & $0 . \mathrm{E}+00$ \\
Ttass & -0.0054656 & 0.000966 & 32.02944 & $2 . \mathrm{E}-08$ \\
Chrrat & 0.00274188 & 0.051841 & 0.002797 & .95782 \\
Nlrat & 0.33753149 & 0.003501 & 9295.215 & $0 . \mathrm{E}+00$ \\
Tsprd & -0.0007912 & 0.000431 & 3.374379 & .06622 \\
Baasprd & 0.00867081 & 0.000302 & 827.064 & $0 . \mathrm{E}+00$ \\
Netimarg & 0.20467051 & 0.013474 & 230.7449 & $4 . \mathrm{E}-52$ \\
Scale & 0.25788714 & 0.000432 & &
\end{tabular}


Table 3

Loan Sales, Full Sample (continued)

B. Ordinary Least Squares Estimation

$\begin{array}{lcrcrr}\text { Source } & \text { DF } & \begin{array}{c}\text { Sum of } \\ \text { Squares }\end{array} & \begin{array}{c}\text { Mean } \\ \text { Square }\end{array} & \text { F Value } & \text { Prob>F } \\ \text { Model } & 19 & 34.7539 & 1.82915 & 75.377 & 0.0001 \\ \text { Error } & 476821 & 11570.8790 & 0.02427 & & \\ \text { C Total } & 476840 & 11605.6329 & & & \\ & \text { Root MSE } & 0.15578 & \text { R-Square } & 0.0030 & \\ & \text { DEP Mean } & 0.00831 & \text { Adj R-Sq } & 0.0030 & \\ & \text { C.V. } & 1875.5726 & & & \end{array}$

\begin{tabular}{lcccc}
\multicolumn{1}{c}{ Variable } & $\begin{array}{c}\text { Parameter } \\
\text { Estimate }\end{array}$ & $\begin{array}{c}\text { Standard } \\
\text { Error }\end{array}$ & $\begin{array}{c}\text { T for H0: } \\
\text { Parameter }=0\end{array}$ & Prob $>|\mathrm{T}|$ \\
Intercept & 0.020186 & 0.008218 & 2.456 & 0.0140 \\
DUMSE & -0.002313 & 0.001073 & -2.156 & 0.0311 \\
DUMMW & 0.002226 & 0.001013 & 2.198 & 0.0280 \\
DUMHP & 0.004697 & 0.001063 & 4.418 & 0.0001 \\
DUMSW & 0.005294 & 0.001135 & 4.664 & 0.0001 \\
DUMWE & 0.004441 & 0.001293 & 3.434 & 0.0006 \\
DSZ1 & -0.032005 & 0.003979 & -8.043 & 0.0001 \\
DSZ2 & -0.032382 & 0.003649 & -8.874 & 0.0001 \\
DSZ3 & -0.031036 & 0.003401 & -9.125 & 0.0001 \\
DSZ4 & -0.026214 & 0.003507 & -7.476 & 0.0001 \\
DSZ5 & -0.028075 & 0.003302 & -8.502 & 0.0001 \\
Caprat & 0.098796 & 0.004053 & 24.378 & 0.0001 \\
Hotrat & 0.018312 & 0.002006 & 9.127 & 0.0001 \\
Holdco & 0.004878 & 0.000516 & 9.451 & 0.0001 \\
Chrrat & 0.107538 & 0.023751 & 4.528 & 0.0001 \\
Nlrat & 0.029860 & 0.001623 & 18.398 & 0.0001 \\
Ttass & -0.001368 & 0.000470 & -2.913 & 0.0036 \\
Tsprd & 0.000201 & 0.000210 & 0.955 & 0.3394 \\
Baasprd & 0.000913 & 0.000149 & 6.115 & 0.0001 \\
Netimarg & 0.065087 & 0.011991 & 5.428 & 0.0001
\end{tabular}

Source: Authors' calculations. 
Table 4

Loan Purchases, Full Sample

A. Tobit Results

Noncensored Values $=77,199$

Left Censored Values $=171.801$

Observations with Missing Values $=0$

Log Likelihood for Normal -69891.92992

\begin{tabular}{lrrrl}
\multicolumn{1}{c}{ Variable } & Estimate & Std Err & Chi-square & PR>CHI \\
Intercept & -0.2893156 & 0.006884 & 1766.465 & $0 . E+00$ \\
DSZ1 & 0.0193331 & 0.002924 & 43.70545 & $4 . \mathrm{E}-11$ \\
DSZ2 & 0.0190138 & 0.002576 & 54.47983 & $2 . \mathrm{E}-13$ \\
DSZ3 & 0.0216524 & 0.002306 & 88.19798 & $6 . \mathrm{E}-21$ \\
DSZ4 & 0.0301998 & 0.002064 & 213.9918 & $2 . \mathrm{E}-48$ \\
DSZ5 & 0.0492004 & 0.002156 & 520.981 & $0 . \mathrm{E}+00$ \\
DUMSE & 0.0313325 & 0.001003 & 976.3977 & $0 . \mathrm{E}+00$ \\
DUMHP & 0.0637088 & 0.000895 & 5069.116 & $0 . \mathrm{E}+00$ \\
DUMMW & 0.0504531 & 0.000905 & 3104.611 & $0 . \mathrm{E}+00$ \\
DUMSW & 0.0539846 & 0.001159 & 2169.572 & $0 . \mathrm{E}+00$ \\
DUMWE & 0.0405669 & 0.000983 & 1703.577 & $0 . \mathrm{E}+00$ \\
Caprat & 0.0867370 & 0.001809 & 2298.983 & $0 . \mathrm{E}+00$ \\
Hotrat & -0.0096087 & 0.001222 & 61.80625 & $4 . \mathrm{E}-15$ \\
Holdco & 0.0298059 & 0.000539 & 3059.936 & $0 . \mathrm{E}+00$ \\
Chrrat & -0.4778476 & 0.007279 & 4309.519 & $0 . \mathrm{E}+00$ \\
Nlrat & 0.0315988 & 0.001278 & 602.3675 & $0 . \mathrm{E}+00$ \\
Ttass & 0.0084245 & 0.000385 & 479.7353 & $0 . \mathrm{E}+00$ \\
Lsrat & 1.8755314 & 0.001059 & 3136809 & $0 . \mathrm{E}+00$ \\
Tsprd & 0.0001882 & 0.000189 & 0.993242 & 0.3189 \\
Baasprd & -0.0003667 & 0.000347 & 1.119754 & 0.2899 \\
Netimarg & -0.2605996 & 0.005501 & 2244.36 & $0 . \mathrm{E}+00$ \\
Scale & 0.1009503 & 0.000057 & & \\
& & & &
\end{tabular}


Table 4

Loan Purchases, Full Sample (continued)

B. Ordinary Least Squares Estimation

\begin{tabular}{lrrccr} 
Source & \multicolumn{1}{c}{ DF } & \multicolumn{1}{c}{$\begin{array}{c}\text { Sum of } \\
\text { Squares }\end{array}$} & $\begin{array}{c}\text { Mean } \\
\text { Square }\end{array}$ & F Value & Prob $>$ F \\
Model & 20 & 28885.8250 & 1444.2912 & 156039.918 & 0.0001 \\
Error & 248979 & 2304.5269 & 0.00926 & & \\
C Total & 248999 & 31190.3519 & & & \\
& Root MSE & 0.096219 & R-Square & 0.9261 & \\
& DEP Mean & 0.00548 & Adj R-Sq & 0.9261 & \\
& C.V. & 1755.3217 & & &
\end{tabular}

\begin{tabular}{lrccc}
\multicolumn{1}{c}{ Variable } & $\begin{array}{c}\text { Parameter } \\
\text { Estimate }\end{array}$ & $\begin{array}{c}\text { Standard } \\
\text { Error }\end{array}$ & $\begin{array}{c}\text { T for H0: } \\
\text { Parameter=0 }\end{array}$ & Prob $>|\mathrm{T}|$ \\
Intercept & -0.034647 & 0.007155 & -4.842 & 0.0001 \\
DUMSE & 0.003665 & 0.000902 & 4.065 & 0.0001 \\
DUMMW & -0.000720 & 0.000857 & -0.840 & 0.4012 \\
DUMHP & -0.003484 & 0.000907 & -3.840 & 0.0001 \\
DUMSW & 0.001379 & 0.001003 & 1.375 & 0.1691 \\
DUMWE & -0.006751 & 0.001083 & -6.233 & 0.0001 \\
DSZ1 & 0.048540 & 0.003303 & 14.698 & 0.0001 \\
DSZ2 & 0.051719 & 0.002994 & 17.272 & 0.0001 \\
DSZ3 & 0.052170 & 0.002750 & 18.968 & 0.0001 \\
DSZ4 & 0.045400 & 0.002785 & 16.299 & 0.0001 \\
DSZ5 & 0.059611 & 0.002593 & 22.990 & 0.0001 \\
Caprat & -0.031912 & 0.003423 & -9.323 & 0.0001 \\
Hotrat & -0.027386 & 0.001717 & -15.950 & 0.0001 \\
Holdco & -0.001370 & 0.000451 & -3.038 & 0.0024 \\
Chrrat & -0.459698 & 0.021492 & -21.390 & 0.0001 \\
Nlrat & -0.022235 & 0.001383 & -16.075 & 0.0001 \\
Ttass & -0.000252 & 0.000417 & -0.604 & 0.5461 \\
Tsprd & 0.000471 & 0.000165 & 2.850 & 0.0044 \\
Baasprd & -0.000948 & 0.000325 & -2.919 & 00035 \\
Netimarg & -0.058256 & 0.008956 & -6.498 & 0.0001 \\
Lsrat & 1.776079 & 0.001006 & 1765.887 & 0.0001
\end{tabular}

Source: Authors' calculations. 
A. Tobit Results

Noncensored Values $=25,812$

Left Censored Values $=45,886$

Observations with Missing Values $=22,988$

Log Likelihood for Normal 434.14330438

\begin{tabular}{lclrc}
\multicolumn{1}{c}{ Variable } & Estimate & Std Err & Chi-square & PR>CHI \\
& & & & \\
Intercept & -0.0619416 & 0.019954 & 9.636142 & .00191 \\
DSZ1 & -0.1015317 & 0.008596 & 139.5094 & $3 . E-32$ \\
DSZ2 & -0.1001501 & 0.007671 & 170.4373 & $6 . E-39$ \\
DSZ3 & -0.0888576 & 0.006895 & 166.0903 & $5 . E-38$ \\
DSZ4 & -0.0565355 & 0.00666 & 72.05552 & $2 . E-17$ \\
DSZ5 & -0.0489107 & 0.006005 & 66.34139 & $4 . E-16$ \\
DUMSE & 0.01206392 & 0.002635 & 20.9582 & $5 . E-06$ \\
DUMHP & 0.06878222 & 0.0026 & 699.8462 & $0 . E+00$ \\
DUMMW & 0.05287126 & 0.002471 & 457.9398 & $0 . E+00$ \\
DUMSW & 0.03868639 & 0.002972 & 169.4287 & $1 . \mathrm{E}-38$ \\
DUMWE & 0.04023529 & 0.002994 & 180.5944 & $4 . \mathrm{E}-41$ \\
Caprat & 0.03791886 & 0.011395 & 11.07438 & .00088 \\
Hotrat & 0.09700892 & 0.004739 & 419.1185 & $0 . \mathrm{E}+00$ \\
Holdco & 0.02412593 & 0.001307 & 340.8888 & $4 . \mathrm{E}-76$ \\
Ttass & -0.0078344 & 0.001182 & 43.94982 & $3 . \mathrm{E}-11$ \\
Chrrat & 2.29200869 & 0.023562 & 9462.659 & $0 . \mathrm{E}+00$ \\
Nlrat & 0.12738075 & 0.003998 & 1015.135 & $0 . \mathrm{E}+00$ \\
Offrat & 0.00028522 & 0.000329 & 0.751804 & .38591 \\
Hltrat & 0.08909128 & 0.037431 & 5.665175 & .01730 \\
Tsprd & -0.0020317 & 0.001181 & 2.96052 & .08532 \\
Bassprd & -0.0032983 & 0.001692 & 3.801229 & .05121 \\
Netimarg & 0.55228731 & 0.006441 & 7351.189 & $0 . \mathrm{E}+00$ \\
Scale & 0.11305529 & 0.000502 & &
\end{tabular}


Table 5

Loan Sales, HLT Sample (continued)

B. Ordinary Least Squares Estimation

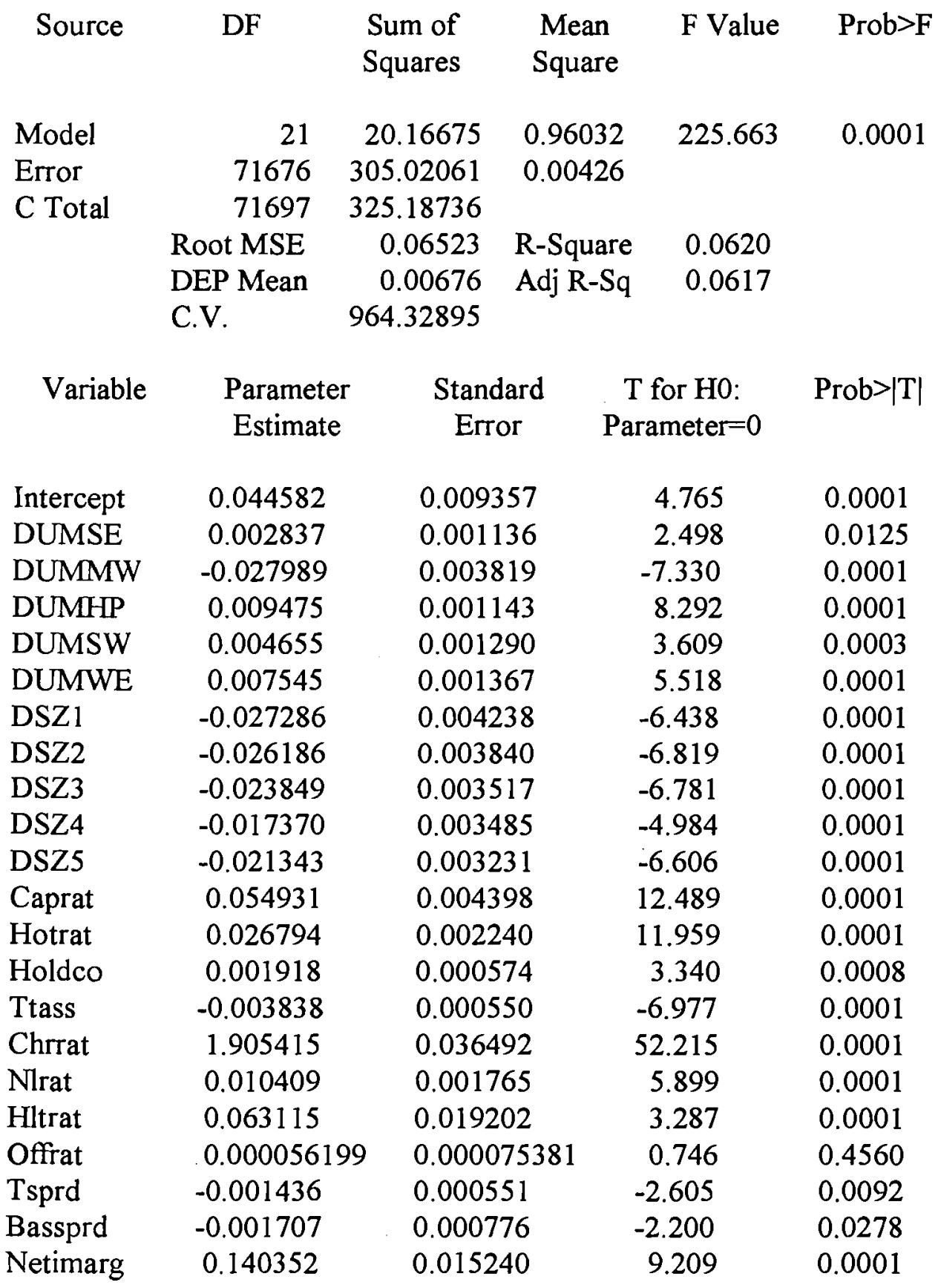

Source: Authors' calculations. 
Table 6

Loan Purchases, HLT Sample

A. Tobit Results

Noncensored Values $=22,098$

Left Censored Values $=49,600$

Observations with Missing Values $=22,988$

Log Likelihood for Normal 9632.9548943

\begin{tabular}{lclrc}
\multicolumn{1}{c}{ Variable } & Estimate & \multicolumn{1}{c}{ Std Err } & Chi-square & PR $>$ CHI \\
Intercept & -0.1095986 & 0.012046 & 82.77916 & $9 . \mathrm{E}-20$ \\
DSZ1 & -0.026952 & 0.005133 & 27.5754 & $2 . \mathrm{E}-07$ \\
DSZ2 & -0.0279432 & 0.004576 & 37.2888 & $1 . \mathrm{E}-09$ \\
DSZ3 & -0.0262942 & 0.004098 & 41.17716 & $1 . \mathrm{E}-10$ \\
DSZ4 & -0.0115984 & 0.003939 & 8.668539 & .00324 \\
DSZ5 & -0.0010379 & 0.003527 & 0.086605 & .76854 \\
DUMSE & 0.02312243 & 0.001714 & 182.007 & $2 . \mathrm{E}-41$ \\
DUMHP & 0.05283154 & 0.0017 & 965.3465 & $0 . \mathrm{E}+00$ \\
DUMMW & 0.0398017 & 0.001628 & 597.4605 & $0 . \mathrm{E}+00$ \\
DUMSW & 0.03366853 & 0.001894 & 315.9122 & $1 . \mathrm{E}-70$ \\
DUMWE & 0.03059283 & 0.001965 & 242.3765 & $1 . \mathrm{E}-54$ \\
Caprat & -0.00552366 & 0.007461 & 54.81358 & $1 . \mathrm{E}-13$ \\
Hotrat & 0.02407541 & 0.002874 & 70.16417 & $5 . \mathrm{E}-17$ \\
Holdco & 0.01916051 & 0.000808 & 562.7826 & $0 . \mathrm{E}+00$ \\
Ttass & 0.00136151 & 0.000714 & 3.631992 & .05668 \\
Chrrat & -0.2111503 & 0.028881 & 53.45238 & $3 . \mathrm{E}-13$ \\
Nlrat & 0.04024019 & 0.00239 & 283.4694 & $1 . \mathrm{E}-63$ \\
Offrat & 0.00183281 & 0.000378 & 23.55218 & $1 . \mathrm{E}-06$ \\
Hltrat & 0.06339505 & 0.021613 & 8.603262 & .00336 \\
Lsrat & 0.20199798 & 0.001419 & 20258.47 & $0 . \mathrm{E}+00$ \\
Tsprd & 0.00234445 & 0.000713 & 10.80731 & .00101 \\
Bassprd & 0.00048049 & 0.000998 & 0.231929 & .63010 \\
Netimarg & -0.2575799 & 0.027171 & 89.87128 & $3 . \mathrm{E}-21$ \\
Scale & 0.6513775 & 0.000319 & &
\end{tabular}




$$
\begin{aligned}
& \text { http://www.clevelandfed.org/Research/Workpaper/lndex.cfm Table } 6 \\
& \text { Loan Sales, HLT Sample (continued) } \\
& \text { B. Ordinary Least Squares Estimation }
\end{aligned}
$$

$\begin{array}{lrrrrr}\text { Source } & \text { DF } & \begin{array}{r}\text { Sum of } \\ \text { Squares }\end{array} & \begin{array}{c}\text { Mean } \\ \text { Square }\end{array} & \text { F Value } & \text { Prob }>\text { F } \\ \text { Model } & 22 & 3.03815 & 0.13810 & 121.918 & 0.0001 \\ \text { Error } & 71675 & 81.18683 & 0.00113 & & \\ \text { C Total } & 71697 & 84.22498 & & & \\ & \text { Root MSE } & 0.03366 & \text { R-Square } & 0.0361 & \\ & \text { DEP Mean } & 0.00448 & \text { Adj R-Sq } & 0.0358 & \\ & \text { C.V. } & 750.50603 & & & \\ & & & & & \end{array}$

\begin{tabular}{lcccc}
\multicolumn{1}{c}{ Variable } & $\begin{array}{c}\text { Parameter } \\
\text { Estimate }\end{array}$ & Standard Error & $\begin{array}{c}\text { T for H0: } \\
\text { Parameter=0 }\end{array}$ & Prob $>|\mathrm{T}|$ \\
Intercept & 0.014114 & 0.004828 & 2.923 & 0.0035 \\
DUMSE & 0.001194 & 0.000586 & 2.038 & 0.0415 \\
DUMMW & 0.002211 & 0.000558 & 3.964 & 0.0001 \\
DUMHP & 0.003392 & 0.000590 & 5.751 & 0.0001 \\
DUMSW & 0.001796 & 0.000666 & 2.699 & 0.0070 \\
DUMWE & 0.002363 & 0.000706 & 3.348 & 0.0008 \\
DSZ1 & -0.004662 & 0.002187 & -2.132 & 0.0330 \\
DSZ2 & -0.004339 & 0.001982 & -2.189 & 0.0286 \\
DSZ3 & -0.004303 & 0.001815 & -2.371 & 0.0178 \\
DSZ4 & -0.002567 & 0.001798 & -1.427 & 0.155 \\
DSZ5 & 0.000296 & 0.001667 & 0.178 & 0.8589 \\
Caprat & -0.000987 & 0.002272 & -0.434 & 0.6640 \\
Hotrat & 0.002796 & 0.001157 & 2.416 & 0.0157 \\
Holdco & 0.001635 & 0.000296 & 5.519 & 0.0001 \\
Ttass & -0.001196 & 0.000284 & -4.214 & 0.0001 \\
Chrrat & -0.007741 & 0.019183 & -0.404 & 0.6866 \\
Nlrat & 0.006852 & 0.000911 & 7.525 & 0.0001 \\
Tsprd & 0.000317 & 0.000284 & 1.115 & 0.2647 \\
Bassprd & 0.000336 & 0.000400 & 0.839 & 0.4015 \\
Netimarg & -0.017724 & 0.007867 & -2.253 & 0.0243 \\
Offrat & 0.000022379 & 0.00003889 & 0.575 & 0.5650 \\
Hlrat & 0.013627 & 0.009908 & 1.375 & 0.1690 \\
Lsrat & 0.092251 & 0.001927 & 47.872 & 0.0001
\end{tabular}

Source: Authors' calculations. 
Table 7

Loan Sales, with Recession Dummy

Tobit Results

Noncensored Values $=182,693$

Left Censored Values $=294,079$

Observations with Missing Values $=4$

Log Likelihood for Normal -130554.2516

\begin{tabular}{lrrrr}
\multicolumn{1}{c}{ Variable } & Estimate & \multicolumn{1}{c}{ Std Err } & Chi-square & PR>CHI \\
Intercept & -0.232 & 0.01658 & 196.23 & $1 . \mathrm{E}-44$ \\
DSZ1 & -0.179 & 0.00753 & 565.33 & $0 . \mathrm{E}+00$ \\
DSZ2 & -0.180 & 0.00679 & 708.77 & $0 . \mathrm{E}+00$ \\
DSZ3 & -0.1513 & 0.00620 & 595.03 & $0 . \mathrm{E}+00$ \\
DSZ4 & -0.0991 & 0.00627 & 249.83 & $3 . \mathrm{E}-56$ \\
DSZ5 & -0.0702 & 0.00575 & 148.91 & $3 . \mathrm{E}-34$ \\
DUMSE & 0.01207 & 0.00234 & 26.601 & $2 . \mathrm{E}-07$ \\
DUMHP & 0.11494 & 0.00227 & 2558.1 & $0 . \mathrm{E}+00$ \\
DUMMW & 0.07988 & 0.00218 & 1342.1 & $0 . \mathrm{E}+00$ \\
DUMSW & 0.1083 & 0.00240 & 2029.9 & $0 . \mathrm{E}+00$ \\
DUMWE & 0.07802 & 0.00267 & 851.72 & $0 . \mathrm{E}+00$ \\
Caprat & -0.0297 & 0.01069 & 7.7199 & .00546 \\
Hotrat & 0.10222 & 0.00394 & 670.39 & $0 . \mathrm{E}+00$ \\
Holdco & 0.05917 & 0.00110 & 2860.37 & $0 . \mathrm{E}+00$ \\
Chrrat & -0.0108 & 0.05223 & 0.04327 & .83521 \\
Nlrat & 0.33804 & 0.00349 & 9352 & $0 . \mathrm{E}+00$ \\
Ttass & -0.0061 & 0.00096 & 40.98 & $2 . \mathrm{E}-10$ \\
Recess & -0.0125 & 0.00179 & 48.77 & $3 . \mathrm{E}-12$ \\
Tsprd & -0.0013 & 0.00043 & 9.1108 & .00254 \\
Baasprd & 0.00852 & 0.00030 & 801.10 & $0 . \mathrm{E}+00$ \\
Netimarg & 0.21088 & 0.01356 & 241.77 & $2 . \mathrm{E}-54$ \\
Scale & 0.25736 & 0.000431 & & \\
& & & &
\end{tabular}

Source: Authors' calculations. 

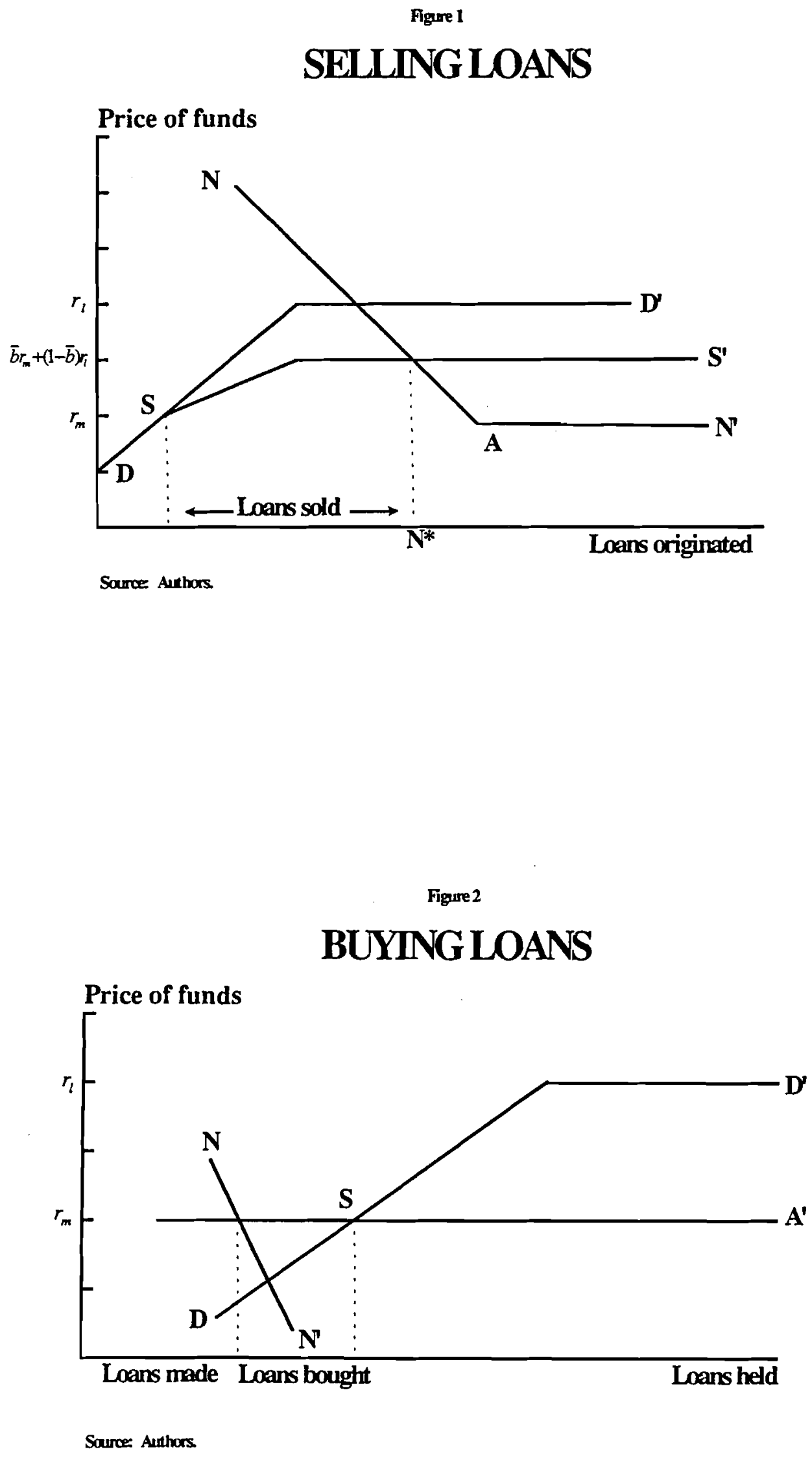
http://www.clevelandfed.org/Research/Workpaper/Index.cfm

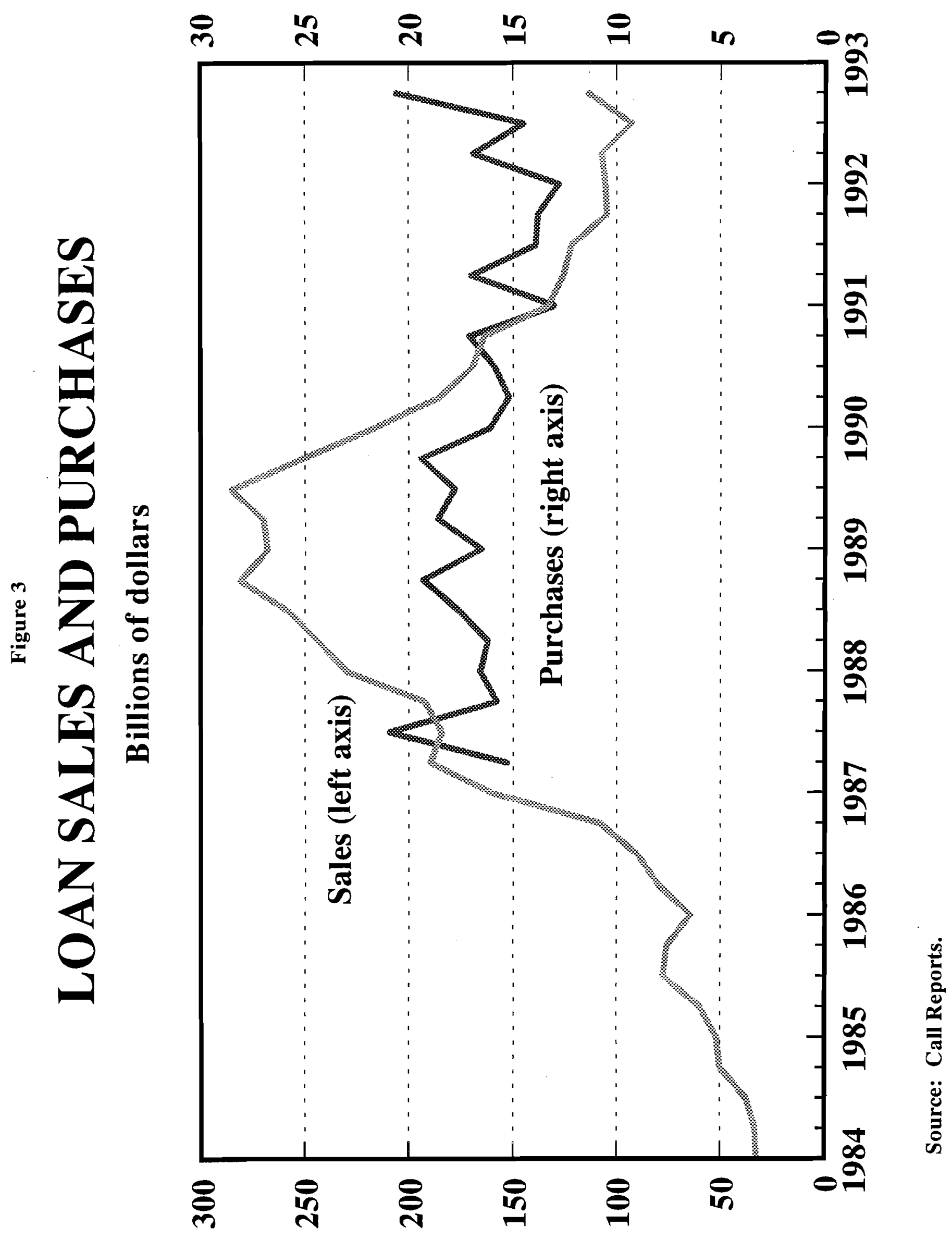




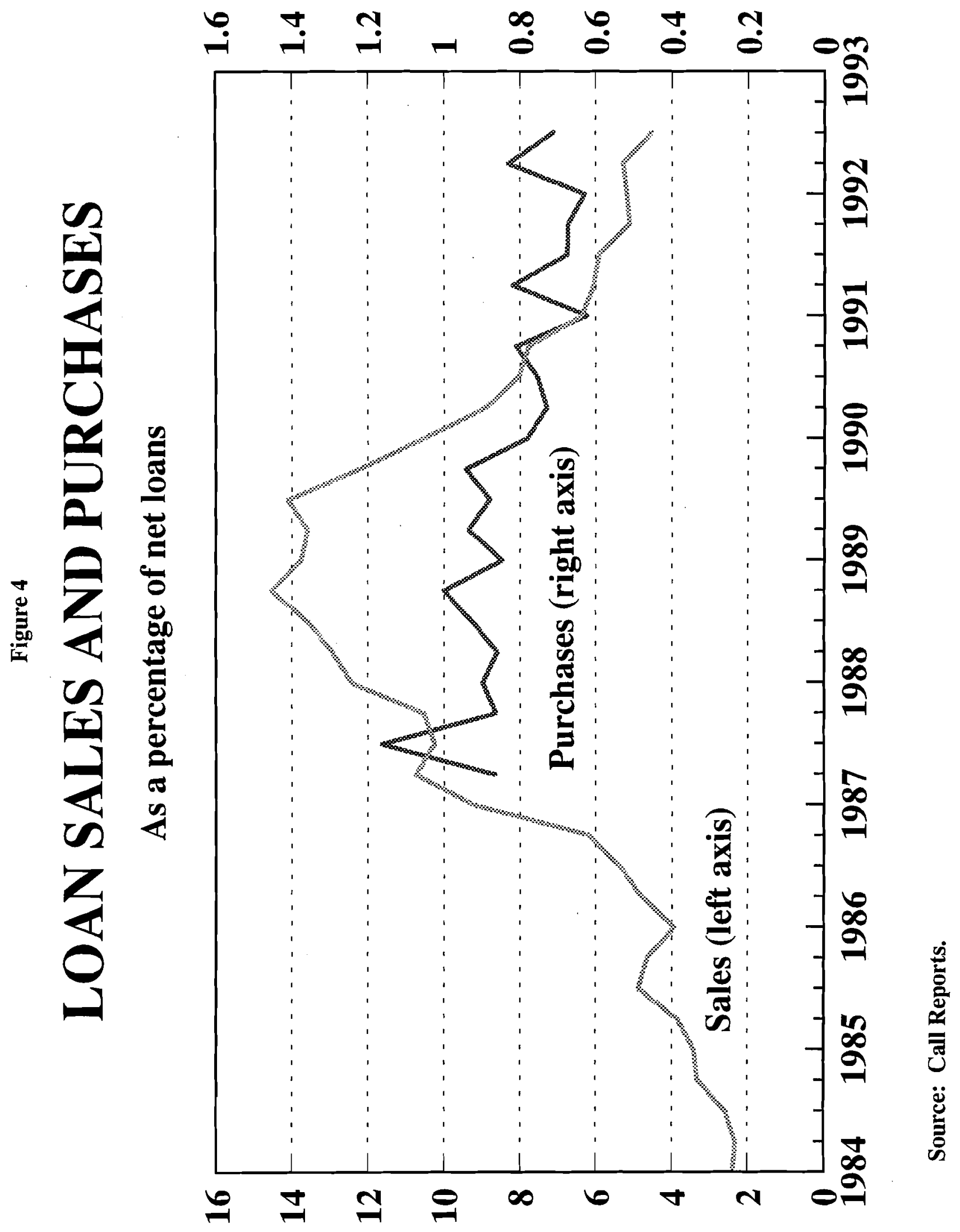




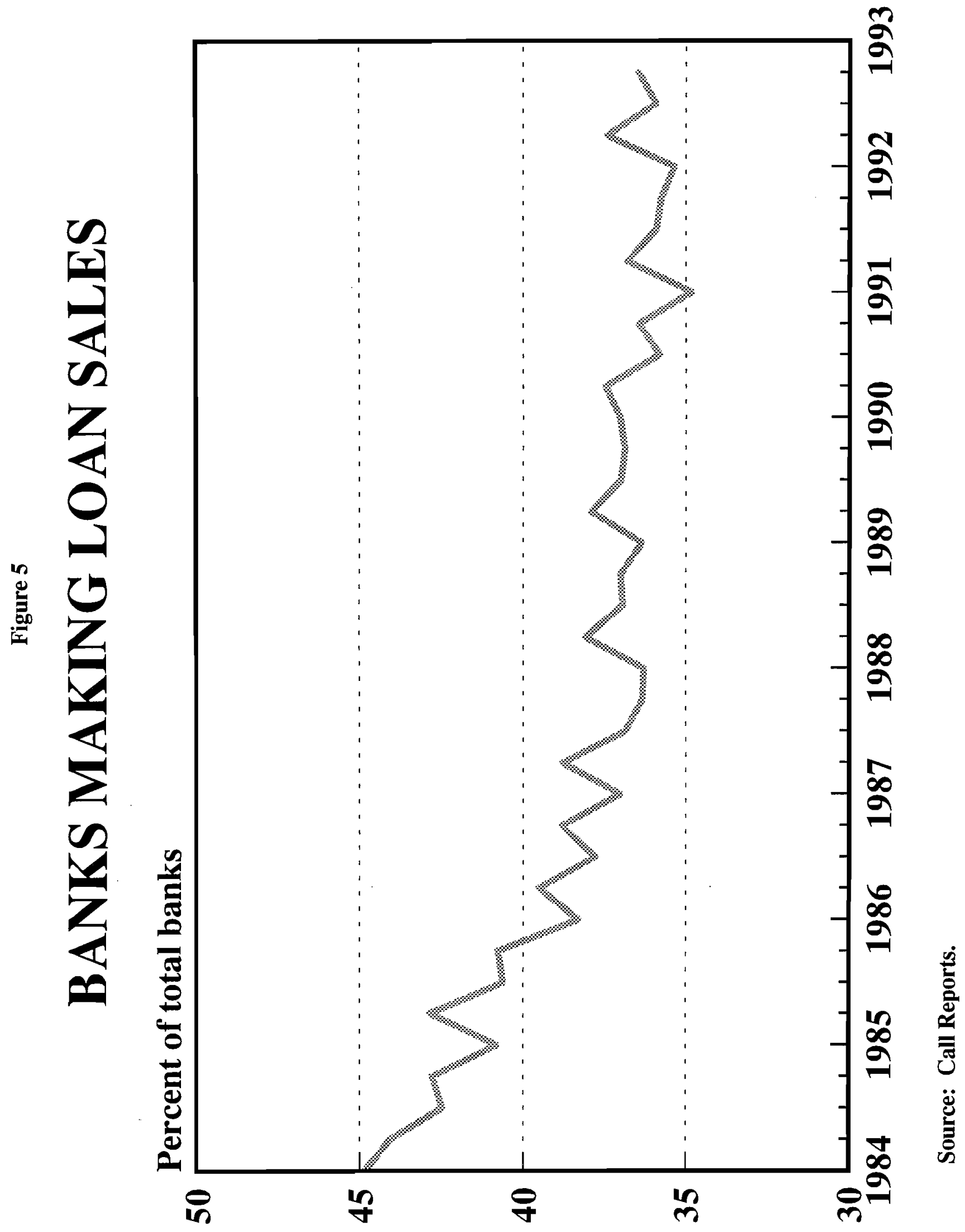




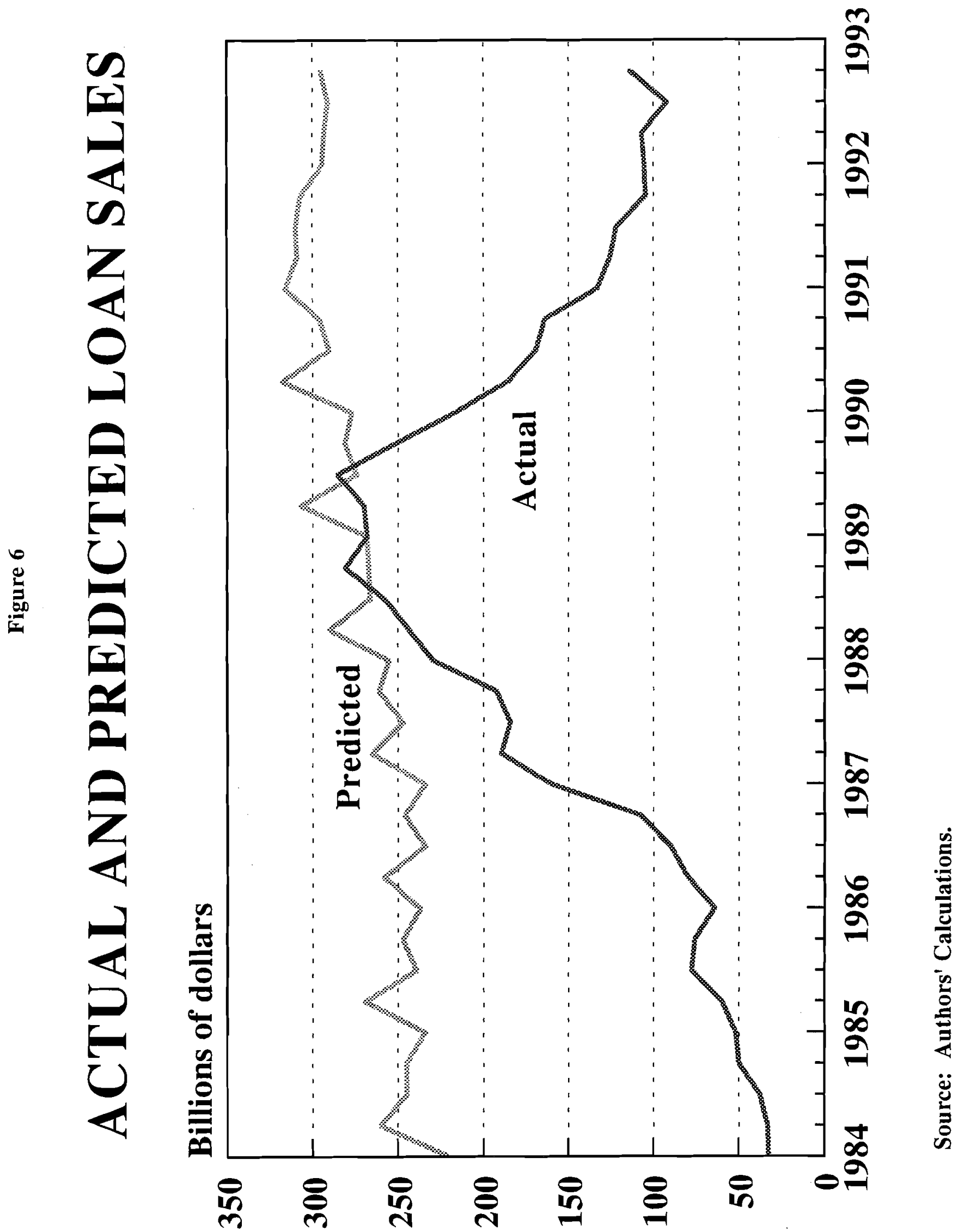




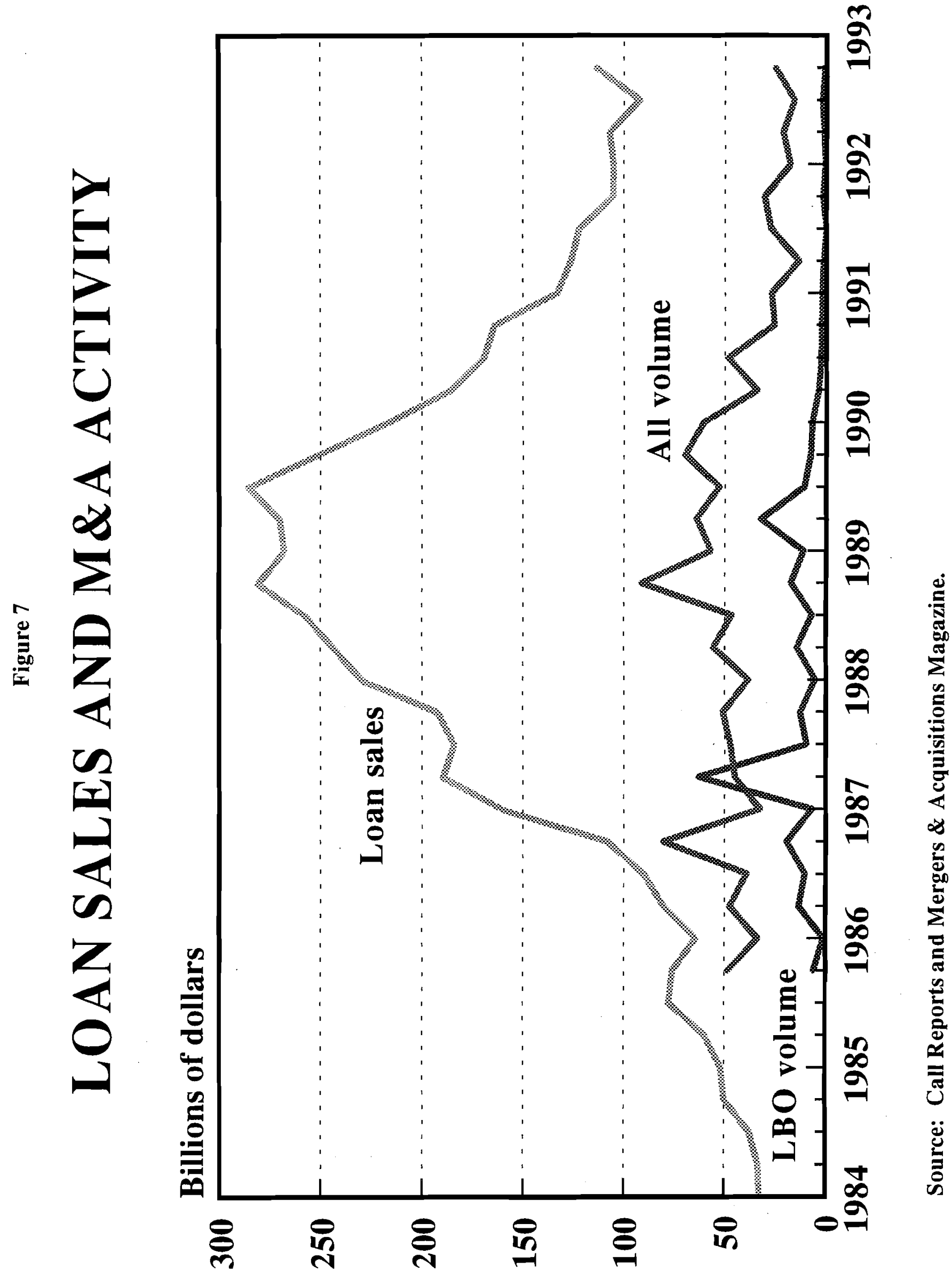




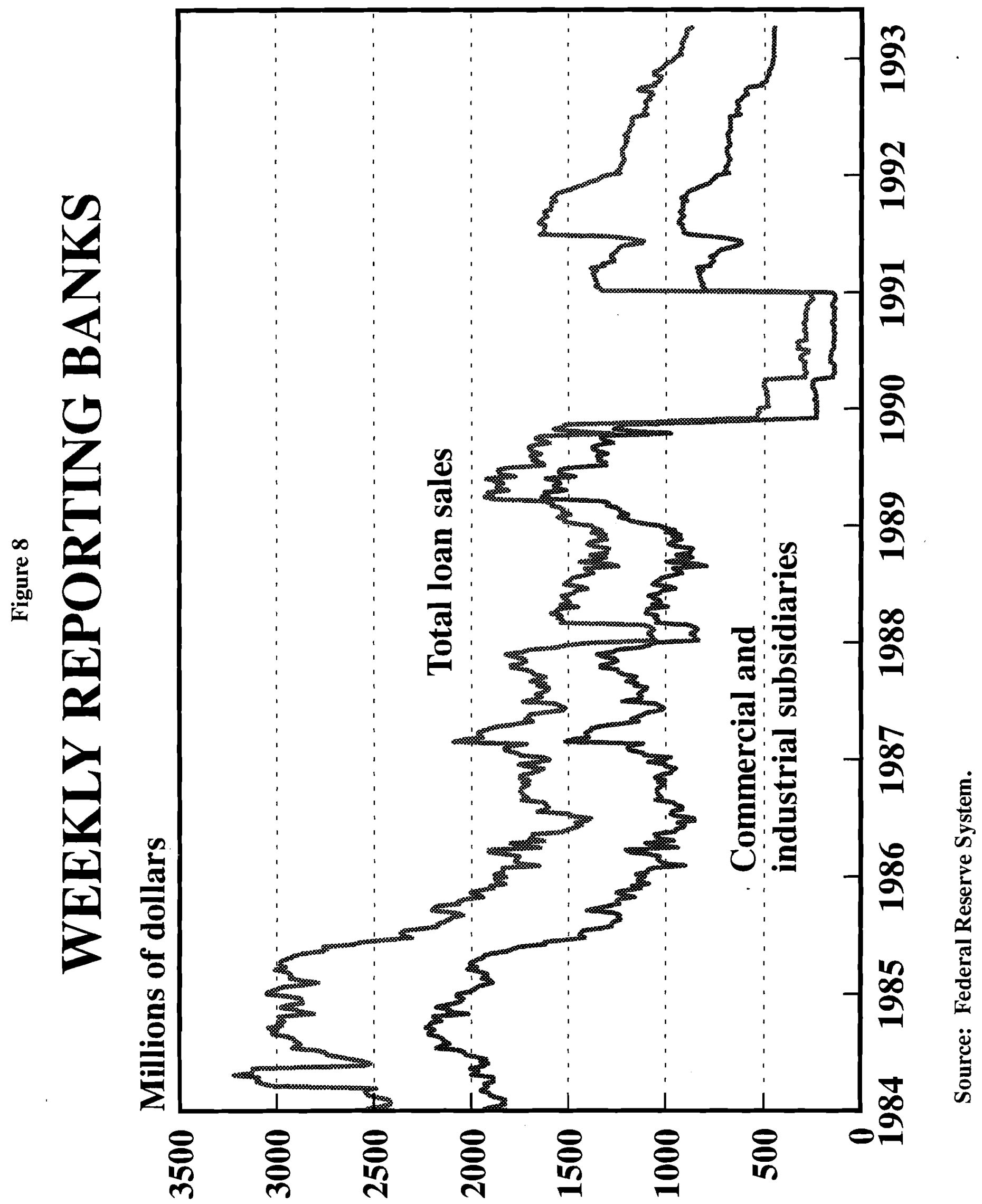

